\title{
BEBERAPA FAKTOR YANG MENENTUKAN TKI DALAM MEMILIH NEGARA TUJUAN SEBAGAI TEMPAT BEKERJA, STUDI DI DESA ARYOJEDING KABUPATEN TULUNGAGUNG
}

\author{
Singgih Susilo ${ }^{1}$ \\ Email: singgih.susilo.fis@um.ac.id
}

\begin{abstract}
Abstrak: Ketimpangan pasar tenaga kerja di Indonesia menyebabkan sebagian angkatan kerja bekerja di luar negeri menjadi Tenaga Kerja Indonesia (TKI). Penelitian ini bertujuan untuk mengetahui beberapa alasan TKI memilih Negara tujuan tertentu sebagai tempat bekerja. Desain penelitian ini kualitatif dengan analisisa data menggunakan model Miles dan Haberman yakni reduksi data, display data, dan verifikasi data. Hasil penelitian bahwa subyek memilih atau menentukan negara tujuan memiliki alasan terentu. Subyek memilihNegara Malaysia karena faktor dekat, bahasa komunikasi, dan bisa illegal. Subyek memutuskan bekerja di Negara Taiwan dan Hongkong lebih tertarik faktorada perlindungan terhadap Tenaga kerja asing, Jaminan libur setiap hari sabtu Subyek yang memilih negara Korea Selatan dikarenakan faktor upah yang sangat tinggi dan disiplin dalam bekerja.
\end{abstract}

Kata Kunci :Penyebaran Negara Tujuan, Pendapatan, TKI.

\section{PENDAHULUAN}

Permasalahan kependudukan di Indonesia merupakan masalah yang serius dan perlu segera penanganan. Terdapat 5 aspek masalah kependudukan yaitu: masalah kelahiran, kematian, migrasi, sumber daya manusia yang tergolong rendah, dan masalah ketenagakerjaan. Masalah ketenagakerjaan secara umum terjadi karena ketimpangan pasar tenaga kerja, yakni pencari kerja lebih banyak dibanding kesempatan kerja yang ada, akibatnya terjadi pengangguran. Terbatasnya kesempatan kerja di Indonesia, salah satunya menyebabkan sebagian tenaga kerja bekerja di luar negeri, menjadi Tenaga Kerja Indonesia (TKI).

Pada umumnya TKI yang bekerja di luar negeri dilatarbelakangi oleh tekanan ekonomi, maka pemikiran para TKI bermuara pada remitansi yang besar. Disinilah ada rasionalitas calon TKI memilih negara tujuan tempat bekerja yang memiliki standar upah tinggi, dengan biaya keberangkatan yang serendah mungkin. Bagi Pemerintah sendiri TKI yang bekerja di luar negeri memberikan sumbangan devisa negara yang tidak kecil. Pemerintah memberikan kemudahankemudahan untuk TKI, seperti yang dilakukan kerja sama antara Kementerian transmigrasi dan tenaga kerja dengan BNI 46. BNI memberikan fasilitas pinjaman, layanan deposito, jasa pengiriman, penukaran mata uang, pelatihan dan penyuluhan bagi TKI. 
Sudah seharusnya perhatian pemerintah terhadap TKI yang bekerja di luar negeri, karena disamping memberikan devisa negara, remitansi secara langsung dapat mengubah keadaan sosial ekonomi keluarga yang lebih baik. Remitansi dapat meringankan kemiskinan keluarga. Permasalahannya tidak semua TKI yang bekerja di luar negeri, selalu menyandang keberhasilan secara ekonomi. Kasus-kasus banyak dialami oleh TKI, terutama tenaga kerja wanita, seperti yang ditayangkan oleh media elektronik televisi ketika pemulangan TKI yang tinggal di bawah jembatan layang di negara Arab Saudi yang diprakarsai oleh pemerintah, terutama tenaga kerja wanitanya,

Pendekatan teori dasar untuk menjelaskan dan menganalisa migrasi TKI yang bekerja di luar negeri adalah model dorong-tarik atau push-pull theoryyang dikemukakan oleh Lee (dalam Susilo,2015). Menurut teori ini ada 4 faktor yang mendorong orang mengambil keputusan untuk bermobilitas yaitu: (a) Faktor-faktor yang terdapat di daerah asal (dorong), (b)Faktor-faktor yang terdapat di daerah tujuan (tarik),(c)Faktor penghalang, dan

Faktor pribadi. Dari empat faktor teori Lee ini yang lebih berperan kepada faktor-faktor yang menentukan pemilihan negara tujuan sebagai tempat bekerja adalah faktor tarik atau faktor yang ada di daerah (negara) tujuan, disamping faktor individu seperti yang dilansir oleh Lee sendiri.

Teori migrasi lainnya yang populer terutama di negara berkembang, adalah teori migrasi berantai. Pada dasarnya teori ini menerangkan tentang proses pengambilan keputusan seseorang untuk meninggalkan kampung halaman yang dikaitkan dengan keberadaan famili atau kawan yang sudah ada di daerah tujuan. Beberapa TKI desa Aryojeding yang bekerja di negara- negara tetangga, salah satu penyebab adanya migrasi berantai (Susilo, 2002).

Bertolak dari teori tersebut banyak TKI di desa Aryojeding yang bekerja di luar negeri tidak terlepas dari teori tersebut, seperti TKI yang sebagian bekerja dinegara Malaysia, Taiwan, Brunai, Hongkong, Singapura maupun di Arab Saudi (Susilo, 2013). TKI memilih dan menentukan bekerja di luar negeri bergantung beberapa faktor baik faktor dorong maupun faktor tarik. Pada kajian ini lebih difokuskan pada faktor-faktor yang ada di negara tujuan.

Fenomena mobilitas tenaga kerja Indonesia yang bekerja di luar negeri diakui selain dapat membantu memecahkan masalah ketenagakerjaan di Indonesia, juga secara mikro sangat membantu pembangunan ekonomi di daerah asal (Susilo,2015).Hal ini diperkuat oleh pendapat Fuller (1980) berpendapat bahwa penghasilan berpengaruh positif terhadap kehidupan ekonomi di daerah asal migran.Sebaliknya Connell (1980) berpendapat bahwa penggunaan hasil TKI luar negeri oleh keluarga migran yang ditinggalkan di desa merupakan pencerminan dari kemiskinan.

Penelitian ini memfokuskan pada faktor-faktor TKI di desa Aryojeding dalam menentukan memilih negara tujuan sebagai tempat bekerja, hal ini sangat perlu dan penting karena dalam proses penentuan pemilihan negara tujuan 
112

Singgih Susilo. Beberapa Faktor Yang Menentukan Tki Dalam Memilih Negara Tujuan Sebagai Tempat Bekerja, Studidi Desa Aryojeding Kabupaten Tulungagung

merupakan suatu kompromi dari faktorfaktor tarik dengan faktor dorong, antara faktor internal dengan faktor ekternal, namun demikian nampak sekali faktor tarik yang ada di negara tujuan lebih mendominasi dalam penentuan pemilihan negara tujuan sebagai tempat bekerja.

\section{METODE}

Penelitian ini dirancang sebagai penelitian survey dengan menggunakan pendekatan kualitatif.Tujuan penelitian ini untuk mengetahui faktoryang menentukan TKI dalam memilih negaratujuan sebagai tempat bekerja. Subjek dalam penelitian ini adalah seluruhTKI yang sedang bekerja di luar negeri atau TKI yang sementara ini ada dirumah, tetapi masih ada keinginan untuk bekerja di luar negeri kembali. Besarnya subyek bergantung pada kejenuhan jawaban dari subyek, artinya apabila jawaban subyek sudah tidak ada variasi, maka penjaringan subyek dihentikan (Fatcan,2009). Analisa data menggunakan tahapan anlisa reduksi data, display data dan verivikasi data (Miles dan Haberman,1984).

\section{HASIL PENELITIAN DAN PEMBA- HASAN}

Berdasarkan hasil penelitian perkembangan TKI di desa Aryojeding dari tahun ke tahun semakin bertambah. Data dari kantor desa mulai tahun 2010 sampai dengan tahun 2013 jumlahnya semakin besar, yakni pada tahun 2010 TKI yang berangkat dan bekerja di luar negeri sebanyak 44 orang, sedangkan pada tahun 2013 meningkat menjadi 91 TKI yang berangkat dan bekerja di luar
negeri.Sedangkan pada tahun 2011 dan tahun 2012 jumlah TKI yang berangkat dan bekerja di luar negeri sebanyak 58 orang dan 76 orang (Kantor Desa,2014).

Negara tujuan TKI yang berasal dari desa penelitian ini sangat bervariasi mulai dari Negara Malaysia, singapura, Brunai Darusalam, Korea Selatan, Arab Saudi, Hongkong, Taiwan dan negara Amerika Serikat. Kecenderungan peningkatan terjadi pada pemilihan negara Taiwan dan Hongkong sebagai negara tujuan tempat bekerja, namun negara Malaysia masih banyak juga sebagai negara tujuan tempat bekerja. Beberapa alasan mereka (TKI) memiliki faktor tersendiri mengapa memilih negara tujuan tersebut.

Berdasarkan hasil penelitian subyek sebagai TKI yang bekerja diberbagai Negara tujuan, memiliki beberpa faktor yang melatarbelakangi baik itu factor dorong dari daerah asal maupun faktor tarik dari daerah tujuan (Lee,1976). Subyek di desa penelitian ini lebih cenderung didominasi karena faktor tarik dinegara tujuan.Secara detail hasil penelitian menjelaskan subyek yang memilih Negara tertentu seperti pada kajian berkut ini

\section{Subyek Yang Bekerja di Negara Tai- wan}

Negara Taiwan merupakan salah satu Negara tujuan sebagai tempat bekerja bagi TKI dari desa Aryojeding.Dari tahun ke tahun calon TKI yang memilih negaraTaiwan terus meningkat, hal ini terlihat dari data kantor desa setempat bahwa pada tahun 2010 sebanyak 16 orang dan meningkat menjadi 41 TKI pada tahun 2013. TKI yang bekerja di Taiwan umumnya tenaga kerja wanita (TKW). 
Hasil penelitian menunjukkan ada tiga subyek yang bekerja di Negara Taiwan, salah satunya subyek yang bernama Niken Dwiati awal menjadi TKW dinegara Malaysia,Selama bekerja di Malaysia, menurut Niken, dia termasuk gagal, karena ketika pulang tidak membawa hasil yang berarti, dan uang yang dikirimkan juga hanya sedikit. Di Malaysia Niken bekerja sebagai penjaga toko. Empat bulan kemudian Niken kembali berangkat ke luar negeri, menjadi TKI di negara Brunai Darussalam, tepatnya pada tahun 2004 sampai tahun 2006 dengan biaya system potong gaji. Pekerjaan di Brunai sangat berbeda dengan ketika bekerja di Malaysia, yakni sebagai baby sitter, dengan status TKI legal atau resmi.Selama bekerja di Brunai, Niken merasa nyaman karena sistem kontraknya jelas. Sepengetahuan Niken, untuk bekerja di Brunai tidak ada TKI yang statusnya illegal. Selama bekerja di Brunai, secara periodik, atau paling lama dua bulan, Niken pulang ke Tulungagung.

Setelah kontrak kerja di Brunai selesai, Niken mencoba bekerja menjadi TKI di Negara Taiwan, sebagai baby siter.Niken mengaku sudah lelah bekerja menjadi TKI di Taiwan.Saat ini dia bekerja di Taiwan hanya mengabiskan kontrak yang tinggal satu setengah tahun, tepatnya kontrak kerjanya habis pada akhir bulan Mei tahun 2013.Niken mengatakan sangat bersyukur, selama menjadi di TKI baik di Brunai maupun di Taiwan mendapatkan majikan yang baik, kecuali ketika di Malaysia. Di Taiwan, Niken bekerja pada keluarga yang mengelola pendidikan non formal, yakni mengelola kursus bahasa Inggris. Keluarga ini memiliki gedung sendiri, dengan jam kerja pendidikan mulai pagi hingga pukul 9 malam.Niken mengasuh anak yang kecil, sedangkan anak yang sudah berumur 6 tahun di asuh oleh baby siter dari Pakistan.

Niken menuturkan bahwa majikannya baik, untuk keperluan sehari-hari, seperti sabun, sampo, maupun minyak wangi untuk dirinya, selalu dibelikan. Setiap hari pekerjaan Niken dimulai saat si anak majikanya itu bangun sampai anak tersebut tidur malam. Niken tidur satu kamar bersama dengan anak majikannya, dalam kamar yang cukup besar ukuran 3x5 m, dengan vasilitas AC, dan TV. Niken menuturkan bahwa fasilitas tidur lebih nyaman di tempat kerja, dibanding dengan kamar dirumahnya. Kegiatan utamanya adalah mengantar sekolah, mengantar sembahyang, dan mengajak jalan-jalan di sekitar rumah.Jika hari minggu tiba dan majikannya pergi untuk berrekreasi, maka Niken pasti diajak.

Ketika ditanya apakah dia bisa melaksanakan kuajibannya sebagai seorang muslimah?Niken merasa sangat bersyukur karena majikannya mendukung untuk menjalankan ibadah sesuai keyakinannya, jadi tidak ada hambatan, walaupun majikannya non Muslim. Ketika oleh peneliti diajukan pertanyaan, apakah kesan dan pesan bekerja di luar negeri, Niken menjawab bahwa bekerja di Taiwan menyenangkan, standar gaji lebih tinggi dibanding dg Malaysia maupun Brunai Darusalam, Ada jaminankeamanan melalui perlindungan kerja oleh negara, baik sebagai tenaga kerja asing maupun sebagai tenaga kerja wanita, hal ini tidak dijumpai pada dua Negara sebelumnya. Di Taiwan majikan menghargai saya sebagai pekerja dan pada hari Sabtu 
114

Singgih Susilo. Beberapa Faktor Yang Menentukan Tki Dalam Memilih Negara Tujuan Sebagai Tempat Bekerja, Studidi Desa Aryojeding Kabupaten Tulungagung

kami dianjurkan untuk libur tidak bekerja, dan harus keluar dari rumah Temuan data lapangan, subyek memilih bekerja di negara Taiwan, prioritas alasan adalah masalah gaji atau penghasilan. Subyek mengutarakan di Negara Taiwan memiliki standar gaji yang tergolong tinggi, dibanding dengan negara-negara lain. Disisi lain untuk bekerja di Negara Taiwan ada kemudahan yang ditawarkan oleh PJTKI, yaitu sistem pemberangkatan TKI melalui potong gaji. Model sistim potong gaji inilah yang sangat membantu bagi calon TKI yang ekonomi keluarganya kurang mampu.

\section{Subyek Yang Bekerja di Negara Hongkong}

Hongkong merupakan salah satu sebagai negara tujuan bagi TKIW di desa Aryojeding, pilihan TKW ini tidak terlepas dari adanya seorang sebagai perantara untuk bekerja di negara Hongkong khususnya calon TKW yang memilih Negara tersebut sebagai tempat bekerja. Salah satu subyek yang bekerja di Negara tersebut adalah Solamah.

Solamah lahir pada tahun 1977 di desa Aryojding, sebagai anak pertama dari tiga bersaudara.Pendidikan Solamah SD diselesaikan di SD Aryojeding, sedangkan SMP diselesaikan di SMP Negeri Sumbergempol Tulungagung. Solamah waktu sekolah dari SD sampai SMP selalu menduduki prestasi limabesar di kelasnya, bahkan ketika kelas 2 di SMP pernah menjadi rangking 1 di kelasnya. Pada waktu itu sangat ingin sekali melanjutkan sekolah ke SLTA..

Pada bulan April, tahun 2008, Ibu Solamah mulai merintis kehidupan baru, dengan menjadi TKI lagi bekerja di
Negara Hongkong.Keberangkatannya melalui PT Sriti Malang, tanpa biaya, tapi melalui pemotongan gaji selama tujuh bulan.Keberangkatan Ibu Solamah menjadi TKI di Hongkong atas jasa Ibu Marem.Ibu Marem,adalah tetangganya merupakan salah satu orang pegawai agen untuk memberangkatan TKI khusus di Negara Hongkong.Ibu Solamah Di Hongkong bekerja menjadi Baby Sister, khususnya mengasuh anak- anak, pada keluarga Cheung Kang Wu.Ibu Solamah mengasuh dua anak, dan sudah tidak mengurusi pekerjaan rumah tangga. Majikan Ibu Solamah mempunyai satu baby sister, dan satu pembantu rumah tangga, pekerjaan ibu Solamah menurutnya tergolong ringan, hanya menurut ibu Solamah majikannya sangat taat dengan agamanya, sehingga apabila ibu Solamah mau mengerjakan sembahyang lima waktu, harus dengan cara-cara sembunyi, bahkan pernah ketika sholat anaknya tahu, ternyata anaknya bilang pada orang tuanya, kemudian intinya kurang diperkenankan.

Ketika oleh peneliti diajukan pertanyaan, mengapa memilih Negara Hongkong sebagai tempat bekerja, Solamah menjawab bahwa bekerja di Hongkong cukup menyenangkan, standar gaji lebih tinggi, perlindungan kerja oleh Negara, Majikan menghargai saya sebagai pekerja. Solamah berusaha untuk bekerja di Hongkong, dengan faktorstandar gaji lebih tinggi dibandingkan standar upah kerja di Malaysia.Solamah mengatakan bahwa bekerja di Hongkong lebih aman, nyaman dan terlindungi oleh pemerintah, sehingga majikan tidak bisa seenaknya. Di Hongkong ada perlindungan tenaga kerja, 
dan ada perlindungan untuk kaum perempuan

\section{Subyek Yang Bekerja di Negara Ma- laysia}

Apabila melihat sejarah awal masyarakat mengenal bekerja di luar negeri, Negara Malaysia sebagai tujuan utama, sampai data tahun 2000, memberikan Negara Malaysia merupakan Negara yang paling banyak dipilih oleh TKI yang berasal dari desa Aryojeding, seperti hasil penelitian Susilo, menemukan hal tersebut. Lebih lanjut penelitian tersebut menemukan fakta, bahwa TKI desa Aryojeding memilih Negara Malaysia sebagai tempat bekerja, ada faktor yang melatarbelakangi diantaranya, Malaysia Negara yang dianggap dekat jaraknya, Negara Malyasia bisa dimasuki oleh TKI Illegal, dan banyaknya TKI yang sebelumnya bekerja di Negara tersebut.Salah satu TKI yang bekerja di Malaysia adalah subyek yang bernama Sumani (51 tahun).Sumani dibesarkan pada keluarga TKI, kakak-adiknya semua menjadi TKI, semua keluarga ini menjadi TKI di Malaysia, kecuali adik perempuannya. Sumani di Malaysia bekerja sebagai tukang bangunan, Sumani termasuk TKI yang bernasib baik dan ulet, karena Sumani berulang kali terkena penggerebekan TKI ilegal oleh Polisi Malaysia, tetapi Sumani merasa bersyukur selalu bisa meloloskan diri, dari pengepungan Polisi Raja Malaysia. Sumani sendiri bekerja di Malaysia secara illegal. Awal keberangkatanya hanya membawa uang secukupnya, untuk biaya tramportasi, Uang tersebut simpanan hasil bekerja sebagai bangunan, dan sebagian dipinjami oleh kakak iparnya.
Sumani termasuk sudah lama bekerja di Malaysia sebagai tukang bangunan, saudara-saudaranya yang lebih dulu bekerja di Malaysia sangat membantunya, dan saudara-saudaranya pula yang mendorong dan mengajak untuk bekerja di Malaysia. Awal-awal bekerja di Malaysia ikut kakaknya, sehari setelah sampai di Malaysia langsung ikut bekerja sebagai tukang pada proyek bangunan yang dikerjakan oleh kakaknya. Setelah dua bulanan sudah banyak teman dan kenalan, ketika proyek bangunan yang dikerjakan kakaknya selesai, dan belum mendapatkan pekerjaan baru sumani diajak temannya mengerjakan bangunan di kota Kualalumpur. Sejak itu mulai Sumani jarang bekerja dengan saudaranya, bahkan sekarang ini menurutnya tempat tinggalpun sudah jauh.

Menurutnya bekerja di negara Malaysia alasannya terasa sangat dekat jarak dengan Tulungagung, Sarana dan Prasarana tranportasi sangat memadai, dengan pesawat terbang hanya membutuhkan waktu 2 jam, justru waktu yang lama ketika sudah sampai Suarabaya masih harus menempuh perjalanan darat kurang lebih membutuhkan waktu 4 jam untuk mencapai rumah di Tulungagung. Bekerja di Malaysia sebagai tukang bangunan dengan status Ilegal, menurutnya hasilnya masih tetap lebih tinggi jika dibandingkan dengan bekerja diTulunggagung.Peluang bisa untuk menjadi pemborong bangunan.Faktor yang paling penting banyaknya TKI di Malaysia, dan komunikasi sehari hari dengan penduduk asli Malaysia menggunakan bahasa Melayu, yang hampir mirip dengan bahasa

Selama di Brunai Achmadi bekerja di bidang listrik, ikut kontraktor listik, ka- 
lau di Indonesia seperti kantor instalatir listrik, dan belum pernah mencoba atau pindah pada pekerjaan lainnya. Bekerja di Negara Brunai bagi Achmad sangat cocok, karena masyarakat di Brunai memiliki keyakinan agama islam yang sama dengan sebagian besar masyarakat Indonesia. Untuk itu apabila nanti tahun depan habis kontrak kerjanya, rencanananya mau memperpanjang kontrak kerja lagi.

Menurut Achmad merasa bersyukur bisa bekerja di negara Islam Brunai Darusalam, sehinnga dirinya kehidupannya sangat terkontrol dengan agamanya, misalnya untuk makanan di Brunai jelasjelas berlabel halal, kemudian saat bekerja, ketika ada suara adzan, dengan otomatis semua karyawan meninggalkan semua pekerjaan, dan bersama-sama pergi ke Masjid yang dianggap paling dekat. Banyak sekali hal-hal kehidupan sehari-hari, yang bernuansa religious, menurutnya selama bekerja di Brunai, belum menemui tempat restoran serperti kafe, apalagi tempat hran remang-remang.

Bekerja di Brunai rasanya masih akan terus dilakukan oleh Achmad, menurutnya kalau bekerja di Tulungagung, rasanya sulit, terutama dari segi umur yang sudah tua, juga karena ijazah yang dimilikinya untuk sekarang tidak berarti. Bekerja di instalatir listrik, Achmad merasa cocok dan senang, disamping jenis pekerjaan sistem borongan, juga pimpinannya sangat baik, dan seperti keluarga hubunganya dengan pimpinannya. Kecocokan bekerja di Brunai selain standar gaji lebih tinggi suasana masyarakatnya yang relegius, seperti ketika ada suara Adzan, maka semua yang bekerja maupun pimpi- nannya berhenti, dan bergegas menuju tempat sembahyang.

Achmad dengan Bekerja di Brunai lebih banyak sukanya, hanya untuk dukanya, jauh dari keluarga, terutama anak-anak masih kecil-kecil dan masih perlu bimbingan. Pekerjaan instalantir listrik di Brunai tidak pernah sepi pekerjaan, kebetulan Achmad ikut CV yang cukup besar, kadang-kadang hari minggu saja harus lembur kerja. Untuk masalah penghasilan, bekerja sistem borongan, bisa mendatangkan penghasilan yang lebih besar, dan diakui oleh Ahmad sendiri setiap bulannya secara rutin bisa mengirim uang lebih banyak, oleh istrinya uang tersebut sebagian ditabung.

Bekerja di luar negeri seperti di negara Brunai Darusalam, sangat menyenangkan karena standar gaji lebih tinggi dibanding bekerja di Indonesia. Brunai yang merupakan Negara Islam, ada kesamaan dengan masyarakat Indonesia yang sebagian besar beragama Islam, sehingga budaya agamanya hampir sama dengan budaya agama masyarakat Tulungagung.

\section{Subyek Yang Bekerja di Negara Korea Selatan}

Korea Selatan merupakan salah satu sebagai negara tujuan bagi TKI di desa Aryojeding, pilihan TKI ini tidak terlepas dari adanya standar gaji yang diterima tergolong tinggi dibanding negara lain. Salah satu subyek yang bekerja di Negara tersebut adalah Suryono.Suryono adalah TKI yang bekerja di Negara Korea Selatan, keluarganya sebagian besar bekerja sebagai TKI di luar negeri.Suryono di Korea Selatan bekerja pada pabrik pengadaan Spare Part untuk mobil Hundai. 
Bekerja di Korea Selatan cukup membanggakan karena mempunyai standar gaji yang lebih tinggi dibanding dengan standar gaji di negara lain seperti Malaysia, Arab Saudi, Singapura maupun negara Hongkong, disamping Korea Selatan memiliki standar gaji yang tinggi, juga bekerja di Korea Selatan keamanan sangat dijamin oleh pemerintah. Selama bekerja di Korea Selatan setiap tahunnya diusahakan bisa pulang terutama pada hari raya Idul Fitri.

Selama dua bulanan Suyono bekerja di spare part sebagai tukang serabutan, yang disuruh kesana dan kemari, setalah diberi kesempatan mengikuti training selama dua minggu, baru bisa bekerja membuat spare part seperti karyawankaryawan lainnya. Bekerja di Korea seperti bekerja dengan mesin, Suyono hanya kusus membuat alat industri seperti gear, yang selanjutnya alat tersebut diselesaikan pada karyawan bagian lain. Menurut Suyono bekerja seperti ini dalam satu bulan sudah bisa betul memahami pekerjaannya, cepat menjadi karyawan yang professional dibidangnya. Lingkungan kerja kelihatan seperti keras, tetapi setelah menjadi karyawan sangat komunikatif dan disiplin, dan kalau membuat kesalahan memang terus dipanggil atasan, dan diberitahu.

Suyono ditempat kerjanya bekerja secara target, kalau bisa melampui target pada jam kerja, biasanya pada akhir bulan ada uang insentif tersendiri, tapi kalau tidak bisa mencapai target, tidak apa-apa, hanya kondite kerjanya kurang bagus, pada umumnya bisa bekerja melampui target, karena satu karyawan hanya menekuni satu jenis pekerjaan, misalnya bagian membuat baut, tidak akan membuat bidang lainnya.

Bekerja di Korea, khususnya untuk bekerja di Idustri, merasa bekerja dengan penuh semangat, kadang-kadang tidak mempunyai rasa capek, tetapi setelah pulang kerja badan terasa capeknya, untuk bekerja di lingkungannya ada makan siang, dan kalau pagi dan sore ada snack, sedangkan kalau minuman tersedia beberapa macam. Oleh perusahaannya minuman terutama diberi vitamin, sehingga karyawan ketika bekerja seperti tidak memiliki rasa capek.Bekerja di Korea sangat disiplin, ketika hari libur, harus rekreasi atau jalan-jalan, maka pada asrama karyawan oleh pengurusnya dianjurkan keluar dari asrama dipersilahkan jalan-jalan atau rekreasi. Sebaliknya ketika masuk kerja, jam 7 pagi, harus sudah siap kerja, terlambat dapat teguran, beberapa kali bisa dipotong gaji. Bagi tenaga kerja asing jarang untuk terlambat, karena kami disediakan tempat, semacam asrama untuk karyawan.

Bekerja di Korea memiliki standar penghasilan yang tergolong tinggi, dan apabila lembur kerja ada insentif yang tinggi pula. Untuk itu bekerja di Korea menurutnya menyenangkan, walaupun kerjanya ditarget seperti mesin, kadangkadang uang lembur hanya selesih sedikit dengan penerimaan gaji pokoknya.Tempat hiburan sangat banyak, sehingga untuk melepas rasa capek sangat mudah dengan cara mencari tempat hiburan. Tidak sukanya bekerja di Korea, karena jauh dari keluarga, terutama anak dan istri, seperti lain-lainnya, apabila rindu keluarga tinggal menelpon lewat handphone, di Korea pulsa sangat murah. Sejujurnya kurang sukanya bahwa beker- 
118

Singgih Susilo. Beberapa Faktor Yang Menentukan Tki Dalam Memilih Negara Tujuan Sebagai Tempat Bekerja, Studidi Desa Aryojeding Kabupaten Tulungagung

ja di Korea, sangat disiplin dalam waktu, disiplin kerja dan tuntutan professional kerja, sehingga ketika membuat kesalahan atau kekilafan tidak ada toleransi sama sekali.

\section{PENUTUP}

Berdasarkan konteks sosial subyek yang bekerja menjadi TKI luar negeri berbagai negara, maka dapat disimpulkan bahwa: (1). Subyek memilih Negara Malaysia sebagai tempat bekerja, karena beberapa alasan antara lain negara Malaysia merupakan Negara yang letaknya dekat dengan Indonesia, memiliki bahasa komunikasi yang mirip dengan bahasa Indonesia, bisa masuk secara ilegal. (2), Subyek memilih Negara Taiwan sebagai tempat bekerja karena memiliki standar gaji cukup tinggi, ada jaminan perlindungan terhadap tenaga kerja asing, wanita oleh negara, dan ada hari libur Sabtu dan Minggu. (3). Subyek memilih Negara Hongkong sebagai tempat bekerja karena alasan, jaminan perlindungan tenaga kerja asing oleh negara, Jaminan hari libur, dan gaji tergolong besar.(4).Subyek yang memlih negara Brunai Darussalam sebagai tempat bekerja,disamping alasan negara Brunai negara yang kuat memegang syariat agama Islam juga dianggap seperti bekerja di negaranya sendiri (5). Subyek yang memilih Negara Korea Selatan sebagai tempat bekerja karena memiliki standar gaji yang paling tinggi, juga negara Korea Selatan memiliki disiplin kerja yang tinggi.

\section{DAFTAR PUSTAKA}

Connell, John. 1980 Remitance and Rural Development: Migration, Dependency and Inequality in The Suoth Pacific. Development study centre. Paper No. 22. Canberra: The Australian National University Press.

Fatchan.A. 2009.Metode Penelitian Kualitatif. Malang: Jenggala Pustaka Utama.

Fuller, Garry (eds), 1980. Urbanization in Developing Nations, Center of Policy Studies, One Dag Hammarkjoid Plaza, New York, USA.

Kantor Desa Aryojeding 2014. Monografi Desa. Aryojeding.

Lee, Everett S. 1975. Suatu Teori Migrasi. Seri Terjemahan No. 3 Yogyakarta: Pusat Penelitian Studi Kependudukan Universitas Gajah Mada.

Mantra. 1994. Mobilitas Sirkuler dan Pembangunan di Daerah Asal. Warta Demografi.

Miles, M. And Haberman,A. Michael.1984. Qualitatif Data Analysis. London: Sage Publication.

Susilo, Singgih, 2002. Hubungan Antara Remitansi dengan Tingkat Kesejahteraan Keluarga pada TKI di Dukuh Dungmanten, Kabupaten Tulungagung,Surabaya: Pasca Sarjana UNAIR (Tesis).

Susilo, Singgihg 2013 .Makna Remitansi bagi TKI dalam Perspektif Fenomenologi Di Kepulauan Bawean, Kabupaten Gresik., Penelitian Fundamental.

Susilo, Singgih, 2015. Studi Tentang Pemahaman TKI terhadap Remitansi yang diperoleh (Kasus di kepulauan Bawean, Gresik).

Susilo, Singgih, 2015. Pemahaman Suami terhadap Wanita yang Bekerja Di Luar negeri Di Desa Aryojeng, Kabupaten Tulungagung (Penelitian BLU, FIS. UM). 